\title{
Promoting Inquiry Learning in Biology Lessons - A Strategy to Introduce Human Reproduction Issues
}

\author{
Gabriel GORGHIU ${ }^{\left.1^{*}\right)}$, Mihaela ANGHEL ${ }^{2)}$, Laura Monica GORGHIU ${ }^{3)}$ \\ ${ }^{1)}$ Faculty of Electrical Engineering, Electronics and Information Technology, Valahia University \\ Targoviste, 2 Regele Carol I, 130024 Targoviste, Romania; ggorghiu@gmail.com \\ 2)“Diaconu Coresi” Gymnasium School, 41 Runcului str., 135100, Fieni, Romania; mihaelabacria@ \\ yahoo.com \\ ${ }^{3)}$ Faculty of Sciences and Arts, Valahia University Targoviste, 2 Regele Carol I, 130024 Targoviste, \\ Romania; lgorghiu@gmail.com \\ ${ }^{*}$ corresponding author, e-mail: ggorghiu@gmail.com
}

BulletinUASVM Horticulture 72(1) / 2015

Print ISSN 1843-5254, Electronic ISSN 1843-5394

DOI:10.15835/buasvmcn-hort:10663

\begin{abstract}
Nowadays, the presence of inquiry learning in the educational process is increasing constantly. Being a popular strategy more and more, it represents a learning process by posing questions mainly generated from learner's experience, interest or curiosity. On the other hand, the teacher plays an active role, designing scenarios for students, with the view to raise their curiosity and perception related to the proposed subjects. More, introducing questions and involving experiences, the learning process become enjoyable for students. When teaching scientific subjects, inquiry-based science education (IBSE) comes as a proper strategy that can raise the students' interest for developing their scientific knowledge, but also for understanding the real world processes and phenomena. In this respect, the European FP7 project entitled "PROFILES - Professional Reflection-Oriented Focus on Inquiry-based Learning and Education through Science" tries to promote the use of IBSE in teacher education and in classroom practice. This paper presents an educational demarche based on IBSE, in the Biology lessons oriented on Human Reproduction. The students were questioned (using a Motivational Learning Environment specific instrument) related to their perception on the introduced subject, but also on the way the Human Reproduction concepts were introduced to them. After the implementation process, as main result, the students' feedback illustrated a positive perception, with real gains in conjunction to concept understanding and relevance for the real life.
\end{abstract} project

Keywords: Active learning, CPD programme, human reproduction, Inquiry-based Science Education, PROFILES

\section{INTRODUCTION}

As a specific form of active learning, the inquiry learning represents a didactic strategy where the students analyze and explore specific problems, trying to offer solutions for their solving. In this respect, the inquiring tasks provide various opportunities for the students, in order to make them to be involved in scientific activities (Edelson, Gording and Pea, 1999). Teachers become facilitators of learning and have mostly the role to help the students in the process of discovering the scientific knowledge. More, this strategy fosters critical thinking and problem solving skills, becoming a significant factor in students' understanding of the processes and phenomena from the real world. The inquiry learning process can be divided into different phases which help teachers to frame instruction. On the other hand, the inquiry learning used within a scientific educational frame allows to define a teaching methodology called Inquiry-based Science Education (IBSE). In this sense, it becomes more effective when students can recognize and validate their learning in settings that can be applied to their own life (Banchi and Bell, 2008). 
IBSE represents also a strategy recommended for improving science education, at international level (Rocard, 2007). Several projects - under the European FP7 programme - have been funded, with a particular focus to promote the use of IBSE in teacher education and in classroom practice. One of those projects - the PROFILES project (http://www.profiles-project.eu, http://profiles. ssai.valahia.ro) - has the goal to raise the selfefficacy of science teachers to take ownership of more effective ways of teaching students, supported by stakeholders. In the frame of the project, in Romania, the teachers were enrolled in the continuous professional development (CPD) programme "PROFILES - Education through Sciences". As results of the CPD programme, the teachers had to design IBSE training modules based on an innovative 3-stage model (Holbrook, 2010) - in order to be implemented in their classrooms. The innovative 3-stages teaching approach model through science education modules is illustrated in figure 1.

\section{MATERIALS AND METHODS}

One of the most interesting designed module was "Could a sterile couple conceive a child?", dedicated to upper secondary students, and implemented during the Biology lessons oriented on Human Reproduction. The Module was implemented in National College "Ienăchiță Văcărescu", Târgovişte - school year 2011/2012 -, being addressed to the $\mathrm{X}^{\text {th }}$ grade students. 28 students took part in all the proposed Module activities, where beside its specific structure and content, the use of computers and Internet enhanced inquiry-based learning. The main research was oriented on how the upper secondary school students perceived an actual but delicate matter (like infertility) in the specific format of a PROFILES Module, by using the innovative 3 -stages model

Science learning stemming, as a learning area of need, from a motivational, contextualised situation

Stage 1
De-contextualisation

The conceptual science

learned on a need-to-

know basis in a science environment Stage 2
Practically, the module proposes activities that allows students to address an important problem met worldwide - the infertility noticed in many young couples. In this context, the students should investigate the case of a young couple, who is unable to conceive a child, despite several attempts over a year. The proposed activities offer to students the opportunity to investigate this case in successive stages, step by step.

The problem is set up under a specific scenario: "Alina and Alexandru form a young couple, who are unable to conceive a child, despite attempts over a year. The young couple is truly concerned about the obstacles encountered for having a child. Let's run a project to find out the causes of couples' infertility and obtain a solution for them in order to conceive a child!"

In the first part, students are asked to study the basic concepts of the anatomy and physiology of the human reproductive system, using various sources of information. The information collected in this stage constitutes the foundation of knowledge on that the following parts of inverstigation are developed. However, before the second part, the students must know the composition of the human reproductive system, its operation and issues related to the female ovarian cycle.

In the second part, the students explore particular issues like: conception and intrauterine development, but also several rules to be taking into account by prospective parents, in order to have a healthy baby. For this purpose, the students gather information from the school manual, anatomy atlas and suggested web sites, having the target to understand those issues in a better way.

The third part allows students to investigate the causes of male and female infertility, visiting the proposed sites. Students present the most important causes of infertility, by illustrating them in a relation to the collected data.

Fig. 1. The proposed PROFILES innovative 3-stages model (Holbrook, 2010) 
In the fourth part, the students assume the role of experts (each students must choose in the group a specific role: doctor, biologist, priest, human rights lawyer), in order to discuss the couple opportunities related to the in-vitro fertilization technique. Students work in groups of four and have to prepare justified answers, using the gained knowledge that could be accessed from the indicated web sites. In the end, each group of students presents to the class the results of their teamwork - responses and decisions related to the couple fertility problems.

\section{RESULTS AND DISCUSSION}

The implementation in the classroom seemed to be quite difficult due to several reasons: it was a lot of work in a short period of time, the students were not accustomed to this kind of activity and they proved to be not so active in the beginning. Even the students had some knowledge about the human reproductive system, many of them did not know what are the system components and how it functions. In the last part of the implementation, the students played the roles of biologist, doctor, priest and lawyer of human rights. It was really interesting to see them taking those roles and listen to their proposed solutions.

On the other hand, the proposed activities led to the achieving of several compentences (Tab. 1).

Students who participated to the implementation of the proposed module were asked to answer to a questionnaire that tried to take a picture related to the Motivational Learning Environment - MoLE (Bolte, 2006). The students expressed their perception related to the subject (Human Reproduction) and their feeling related to the way the subject has been introduced to them, in the respect of three plans: the ideal perspective, the initial perception - before the implementation process, and the final perception - after the implementation process (fig. 2 and fig. 3). In both situations, it can be noticed a concentration of the feed-backs in the range: "fairly enjoyable - enjoyable" and "fairly contented - contented". In addition, the general understanding of the presented subject was satisfactory and met the expectations (fig. 4).

On the other hand, the proposed module targeted to emphasize the importance of the subject for the students' everyday life, and also for the society, in general (fig. 5 and fig. 6). Students became aware of

Tab. 1. Competences achieved by students, during the implementation of the "Could a sterile couple conceive a child?" Module

\begin{tabular}{|c|c|}
\hline Competence & How the competence is acquired \\
\hline $\begin{array}{l}\text { 1. Tactfulness to describe the human } \\
\text { anatomy and physiology reproductive } \\
\text { system }\end{array}$ & $\begin{array}{l}\text { - it is achieved by the students in strong relation to the knowledge } \\
\text { that students have already gained on this subject, but it can be } \\
\text { deeply developed in the first phase of the Module. }\end{array}$ \\
\hline $\begin{array}{l}\text { 2. Deftness to understand certain rules } \\
\text { for future parents in the situation to have } \\
\text { a normal intrauterine development }\end{array}$ & $\begin{array}{l}\text { - it is achieved in the second part of the students' work, when } \\
\text { the teacher is able to notice how well it is clear, by observing the } \\
\text { students' notes (second phase of the Module). }\end{array}$ \\
\hline $\begin{array}{l}\text { 3. Cleverness to identify possible causes } \\
\text { of a couple infertility }\end{array}$ & $\begin{array}{l}\text { - it is achieved depending on the students' curiosity and specific } \\
\text { investigative spirit of their age (third phase of the Module). }\end{array}$ \\
\hline $\begin{array}{l}\text { 4. Cleverness to analyze the couple } \\
\text { possibilities with fertility problems, in } \\
\text { order to have a baby }\end{array}$ & $\begin{array}{c}\text { - it is achieved in the last part of the Module, where the students } \\
\text { assume their role of experts. The teacher notes the proposed } \\
\text { students' arguments and then guide them on how to debate } \\
\text { the pros and cons opinions for the decision to resort to in-vitro } \\
\text { fertilization. }\end{array}$ \\
\hline $\begin{array}{l}\text { 5. Ability to find specific information in } \\
\text { the suggested websites }\end{array}$ & $\begin{array}{l}\text { - it is achieved throughout their investigation activities } \\
\text { whereas students often turn to the proposed web sites. }\end{array}$ \\
\hline $\begin{array}{l}\text { 6. Ability to analyze the selected } \\
\text { information in relation to the proposed } \\
\text { questions }\end{array}$ & $\begin{array}{l}\text { - it is achieved throughout the work done by the students, in order } \\
\text { to move to the next level of investigation. }\end{array}$ \\
\hline
\end{tabular}




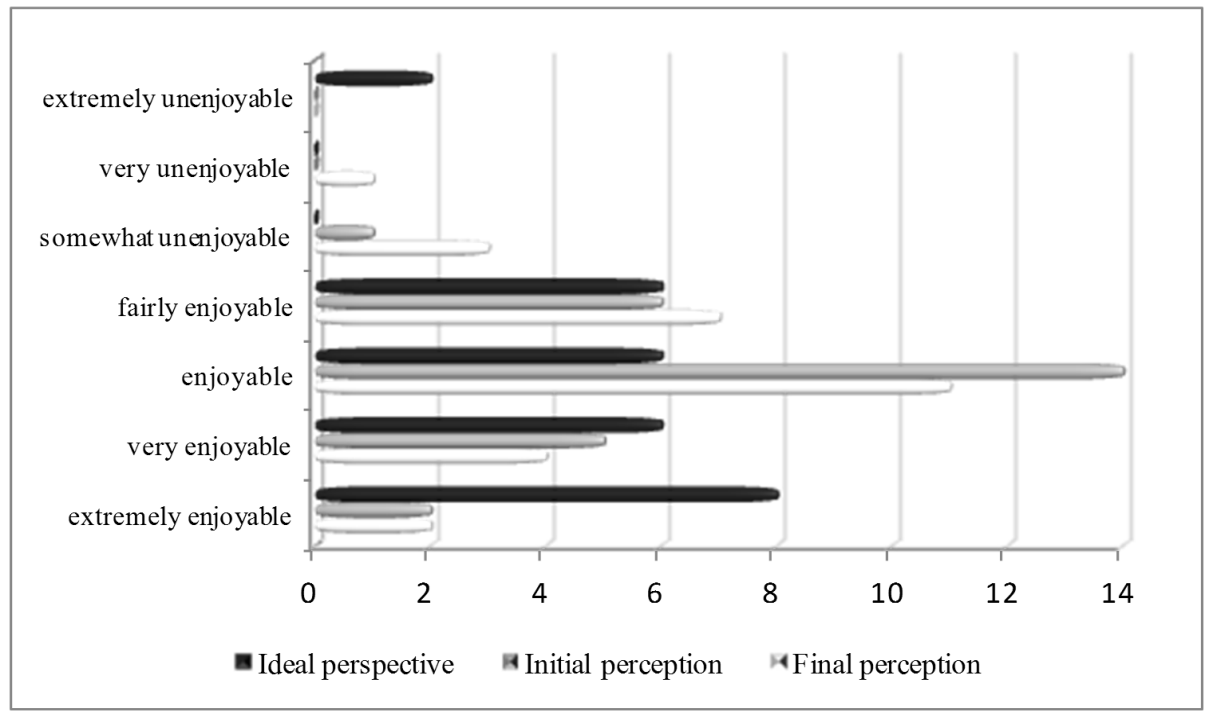

Fig. 2. Students' perception related to the subject introduced by the IBSE module

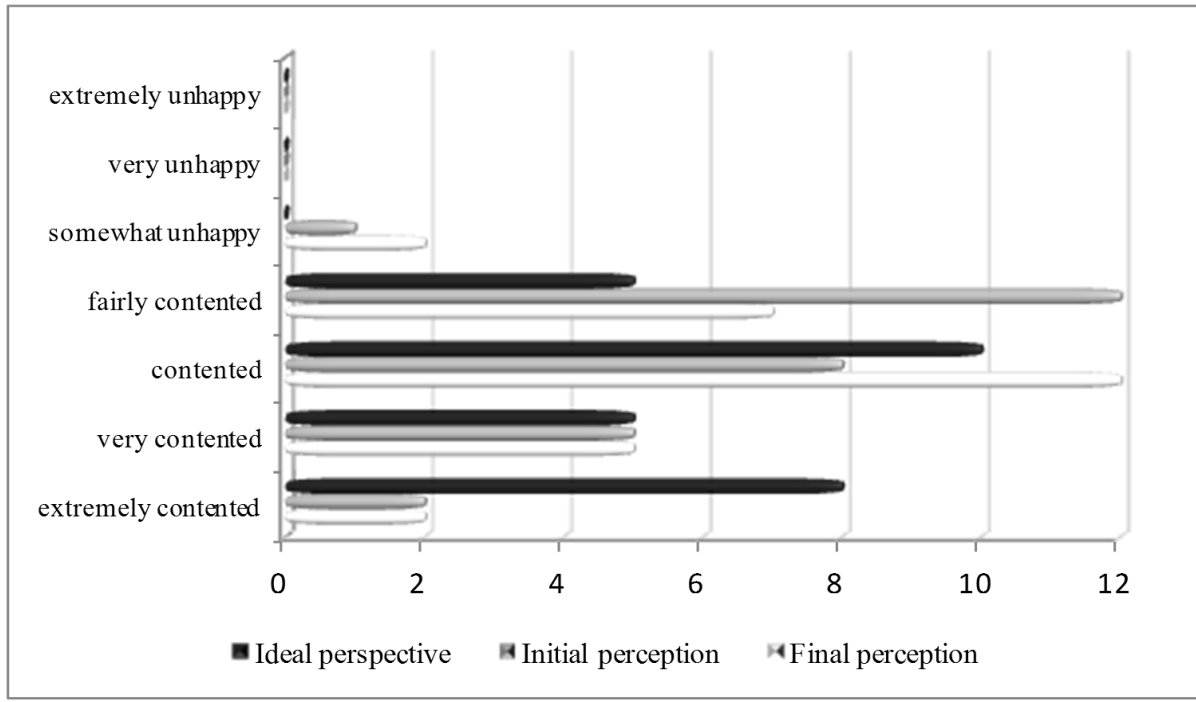

Fig. 3. Students' perception related to the way that the subject has been introduced to them

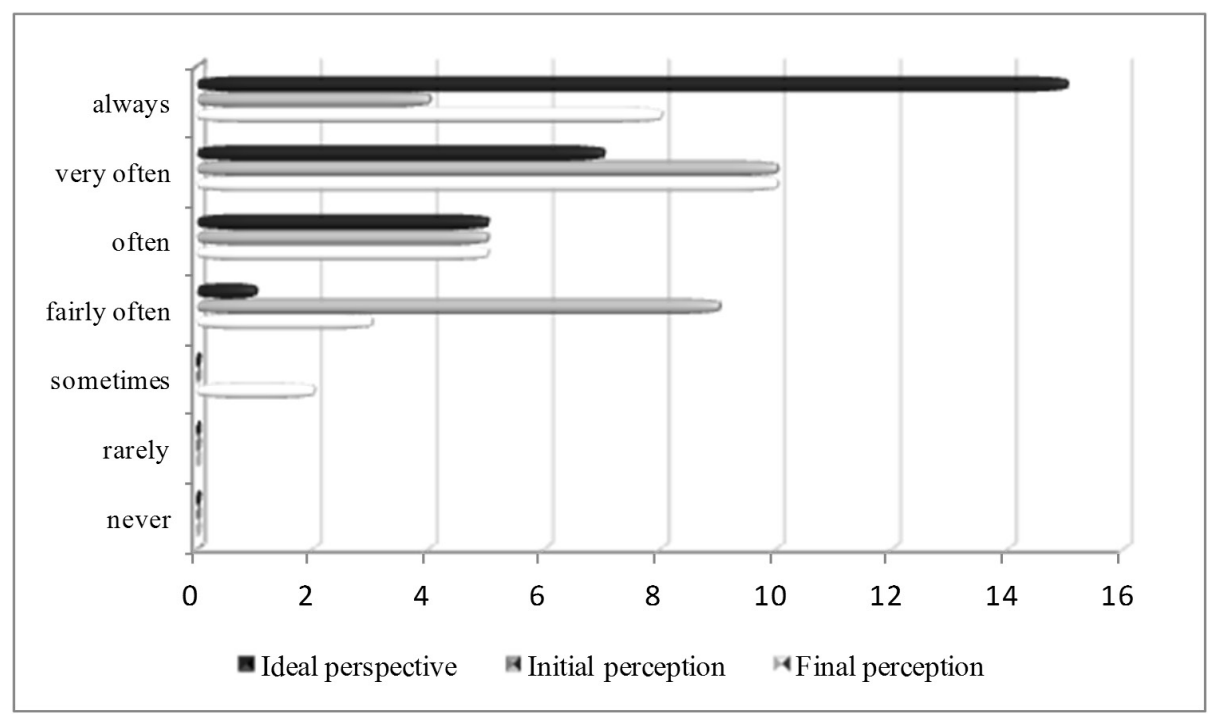

Fig. 4 .Students' perception related to their understanding of the presented subject 


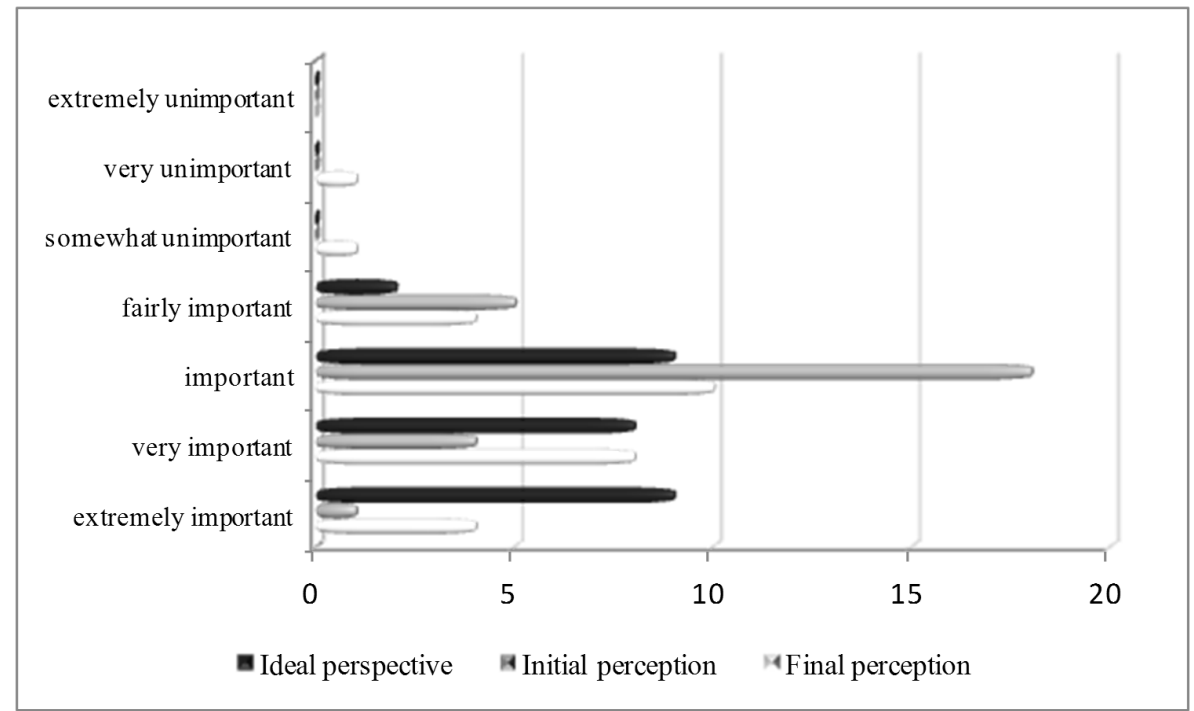

Fig. 5. Students' perception related to importance of the topic for their everyday life

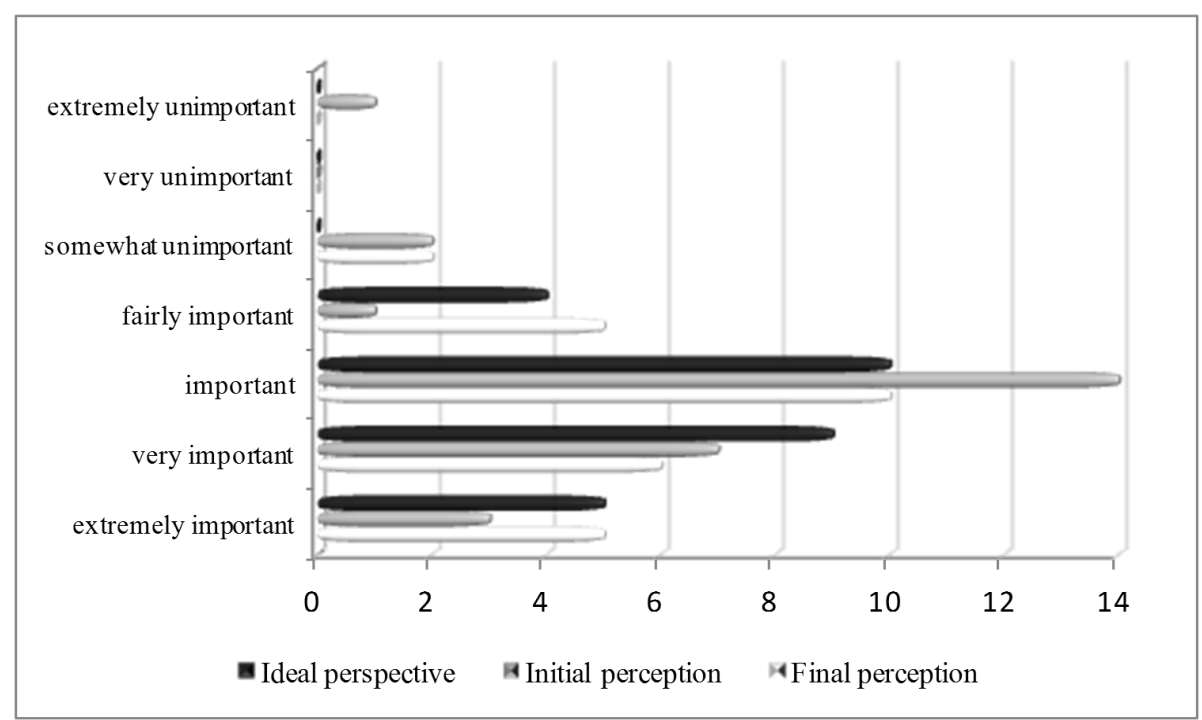

Fig. 6. Students' perception related to importance of the topic for the society

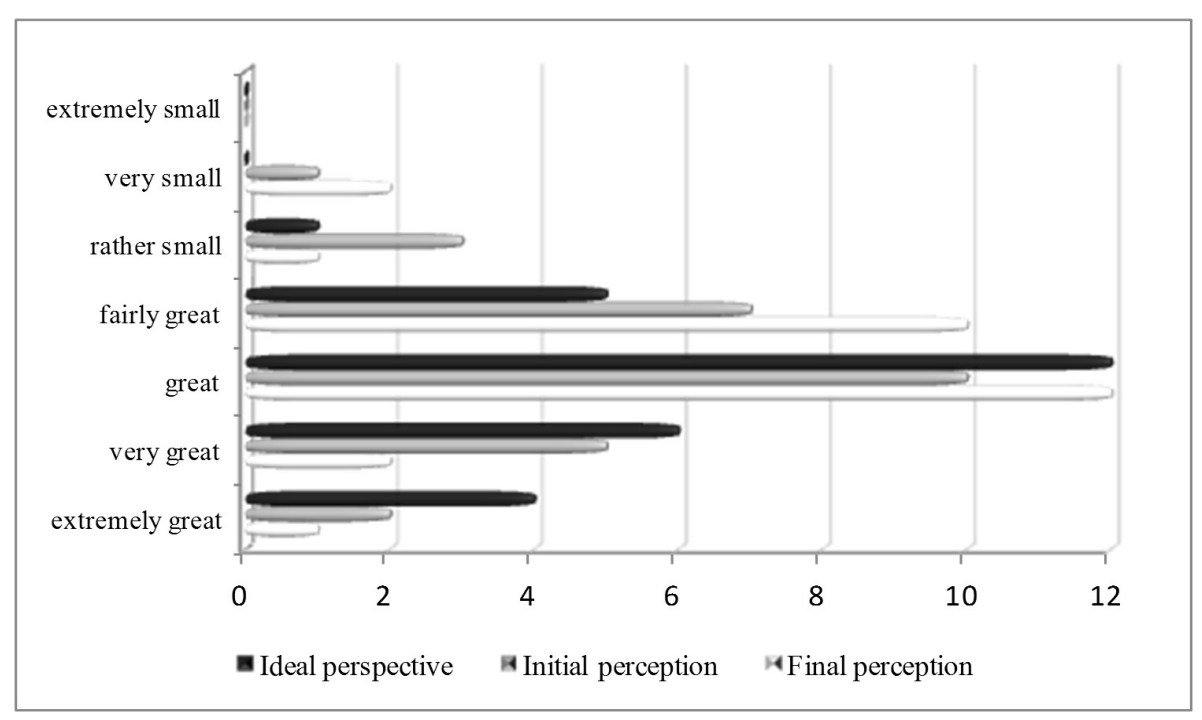

Fig. 7. Students' perception related to the effort made by them for understanding the topic 
what the human reproduction means in a real sense, mostly taking into account that the adolescence comes with changes not just in their physical growth, but also in their psychological, emotional and mental plans. However, the level of the effort made by the students for understanding the discussed subject is considerable (fig. 7). Most of the answers were gathered in the range: "fairly great - great - very great" which shows the necessity for performing a preparation with young students $a$ priori.

\section{CONCLUSION}

Inquiry learning is an important didactic strategy which animates the students in their effort to analyze and investigate specific problems, but also on trying to find solutions for their solving. As illustrated above, during the implementation of a designed PROFILES module - "Could a sterile couple conceive a child?" - in a Biology activity dedicated to upper secondary students, a positive impact of the inquiry-based science education strategy was recorded. The core subject (human reproduction) has been perceived as an important topic for students' everyday life and society. More, the students' feedback encouraged the teacher to improve the module and present it as a good practice issue.
Acknowledgments. The work was funded through the Seventh Framework Programme "PROFILES - Professional Reflection Oriented Focus on Inquiry-based Learning and Education through Science"no. 5.2.2.1-SiS-2010-2.2.1, Grant Agreement No. 266589, under the frame of: Supporting and coordinating actions on innovative methods in Science education: teacher training on inquiry based teaching methods on a large scale in Europe.

\section{REFERENCES}

1. Banchi H, Bell R (2008). The Many Levels of Inquiry. Science and Children, 46(2):26-29.

2. Bolte C (2006). As Good as It Gets: The MoLE-Instrument for the Evaluation of Science Instruction. The Annual Meeting of the National Association for the Research on Science Education (NARST). San Francisco, USA: Polyscript.

3. Edelson DC, Gording DN, Pea RD (1999). Addressing the challenges of inquiry based learning through technology and curriculum design. Journal of the Learning Sciences 8:391-450.

4. Holbrook J (2010). The PROFILES Guidebook. Section B: Operationalising the Professional Development of Teachers. PROFILES project document.

5. Rocard M (chair) (2007). Science education NOW: A renewed pedagogy for the future of Europe. Brussels: European Commision Directorate-General for Research, Science, Economy and Society. Available at: http:// ec.europa.eu/research/science-society/document library/ pdf_06/report-rocard-on-science-education en.pdf. 